\title{
LEAGUE OF RED CROSS SOCIETIES
}

From 27 August to 7 September 1968 at League headquarters, 53 National Red Cross, Red Crescent, and Red Lion and Sun Society representatives held several meetings. The most important was the 87th Session of the League Executive Committee. This was preceded by several meetings, the work of the following two being of particular interest.

\section{Health and Social Welfare}

Red Cross must prepare and train its volunteers to fulfil new health and social welfare tasks in a world of rapidly changing living conditions. This was agreed in Geneva by delegates to the XIIIth Session of the Health and Social Service Advisory Committee of the League of Red Cross Societies.

Delegates represented 15 National Societies, and observers from others and from the World Health Organization, attended. Many were noted public health experts in addition to their Red Cross functions.

At the outset of the meeting League Secretary General Mr. Henrik Beer enumerated the challenges facing Red Cross. They include the changing aspect of communicable diseases with the progress made by medical science, on the one hand, and the resurgence of certain diseases necessitating the mobilization of all available forces, including volunteers, on the other.

Other grave problems face the developing countries such as malnutrition, the lack of proteins, and an increased need for first aid and safety techniques due to expanded industrial and transport facilities. In the more developed nations, the rapid changes in urban living with their corresponding disruptions of family life; the social problems caused by the changing mortality rate - 


\section{IN THE Red Cross World}

these were fields in which Red Cross Societies and their trained workers, including volunteers can play a vital part as auxiliaries to the public authorities.

In a resolution resuming its views on this role, the Committee:

" Recognizing the rapidity of social change in our times in all fields (professional, economic, scientific, industrial) and the role that the Red Cross may play within the community because of the variety of its fields of experience, its possibility of adaptation as well as the varied preparation of its volunteers, stresses the importance of active participation of the Red Cross, as well as its co-operation at various levels whether public or private, and emphasizes the opportunity offered to the Red Cross to help the community to cope with new aspects in the medico-social field in an age of such rapid change.

Among the subjects studied by the Committee were:

- the use of first-aiders after adequate training for social welfare work

- a guide for preparation of a first-aid manual for National Societies

- prevention of accidents in the home

- the question of air transport for the injured and sick and in particular road accident victims

- co-operation between the Red Cross and the World Health Organization

- the role of youth in health education

\section{Youth}

The way must be opened for participation of young people in Red Cross decision-making bodies at the local, national and international levels, delegates urged at the Junior Red Cross Advisory Committee.

Members of the Committee agreed unanimously that " young Red Cross members have a right to a voice in planning and execution of Red Cross programmes, particularly those for youth", 


\section{IN THE Red Cross WorLd}

and recommended that "National Societies open their committees at local and national levels as much as possible to young Red Cross members".

The Committee asked the League Secretary General to " encourage National Societies to include young people" in all delegations to future sessions of the committee.

The main speaker at the meeting was Mr. Peter Kuenstler, of the United Nations Division of Social Affairs, Geneva. He gave the keynote to the discussions in a talk entitled "What is the Red Cross responsibility in the solution of current youth problems".

The 16-member Advisory Committee wound up a three-day session. An extra day had been added to the meeting so that delegates could have more time to review Red Cross Youth programmes in the light of recent youth problems around the world.

They also recommended that a working group study involvement of youth teams in Red Cross development projects in their own or other countries, and that practical international exchange and work programmes and youth study meetings be expanded.

\section{LEAGUE EXECUTIVE COMMITTEE}

The 87th Session of this Committee met under the chairmanship of Mr. José Barroso, Chairman of the Board of Governors of the League. It made important policy decisions affecting the next year of activity of the world federation of Red Cross, Red Crescent and Red Lion and Sun Societies.

The Executive Committee meets every two years, in between meetings of the Board of Governors, which brings together all the League's 110 member Societies.

Among the key points on the agenda are:

- Planning and co-ordination of relief actions at the international and national level;

- International relief actions: revision of principles;

- Plans for assistance to National Societies under the League's Red Cross Development Programme:

- Plans and budgets for 1969 and 1970; 
- Reports of Health and Social Service and Junior Red Cross Advisory Committees;

- Plans for 1969 meetings of the XXIst International Conference of the Red Cross and the XXXth Session of the League Board of Governors, both to be held in Istanbul (Turkey) in AugustSeptember next year;

- Plans for the European Regional Conference of the League, being arranged by the French Red Cross. This Conference will be held at Cannes (France) in April 1969. It will coincide with commemorations of the 50th anniversary of the founding of the League;

- The Red Cross and peace (study of follow-up action on recent resolutions by international Red Cross bodies on this subject).

Delegates and observers representing 55 National Societies attended the meeting.

The Executive Committee adopted a number of resolutions.

We quote below from one concerning the topical problem Red Cross and Peace. Mr. José Barroso referred to this problem in his opening address and told delegates "Red Cross is proof of what can be achieved when good will and comprehension reign among men ". Resolution No. 24 concluded by stating that the Executive Committee

"Solemnly reaffirms its adherence to the principles of human rights, and expresses its concern at any violation and nonobservance of human rights wherever and whenever they may occur in the world,

Appeals to all Governments to settle disputes between nations and peoples by peaceful means to ensure their protection to which the Red Cross has dedicated itself.

Resolution No. 1 states that the Executive Committee decided to admit provisionally to League membership the National Societies of Mali, Kuwait and Guyana, recently recognized by the ICRC. 